\title{
Authentic Assessment in Language Skills Learning
}

\author{
Sukma Sukma ${ }^{1}$, Asriani Abbas ${ }^{2}$, Nurhayati Nurhayati ${ }^{3}$, Kaharuddin Kaharuddin ${ }^{4}$ \\ 1,2,3,4 Universitas Hasanuddin 1 \\ *Corresponding author. Email: sukmasyam86@gmail.com.
}

\begin{abstract}
The 2013 curriculum affirms that formal learning must be student-centred, conducted with a scientific approach, and apply authentic assessment using the principle of assessment of learning that can assess the readiness, process, and learning outcomes of learners as a whole. Authentic assessment as an assessment model is believed to be able to measure the learning success of learners from the affective, cognitive, and psychomotor realms. The problem in this study is 1) how to apply authentic assessment in the learning of language skills; 2 ) what are the forms of authentic assessment used in learning language skills?; and 3) how is the effectiveness of authentic assessments in improving learners' language skills?. The research method used is library research (literature study) from 25 journals and proceedings on authentic assessment in language learning from 2009-2021. The results in this study are 1) in general teachers do not understand and apply authentic assessment in language learning, 2) the most dominant form of authentic assessment used by teachers is performance assessment and portfolio assessment, 3) effective authentic assessment in language learning.
\end{abstract}

Keywords: Authentic Assessment, Language Skills Learning

\section{INTRODUCTION}

Assessment is an activity that cannot be separated from learning activities in general. All learning activities carried out must be accompanied by assessment activities. Without conducting an assessment, a teacher cannot assess and report the learning outcomes of learners objectively. So, assessment is one of the main components in a curriculum. Through assessment can be seen whether the learning objectives contained in the curriculum have been achieved or not. Assessment models are always evolving and refined along with applicable curriculum developments and changes.

Assessments in the 2013 curriculum emphasize authentic assessment. The need to apply authentic assessment in learning because authentic assessment can be used to guarantee real information about the abilities or competencies of students Abdullah [1] states that authentic assessment needs to be applied because authentic assessment is an assessment that is done comprehensively to assess aspects of attitudes, knowledge, skills ranging from inputs, processes, and outputs (output) of learning. Furthermore, Mueller [2] mentioned that authentic assessment needs to be done because of several things, namely (1) authentic assessment is a direct assessment of the ability and competence of learners, (2) authentic assessment provides an opportunity for learners to construct learning outcomes, (3) authentic assessment integrates learning, teaching, and assessment activities, and (4) authentic assessment provides opportunities for learners to demonstrate our diverse abilities.

In line with this opinion, Majid [3] said that authentic assessment is a data collection process including the performance, achievement, motivation and attitude of learners. This is in line with Permendikbud No. 104 of 2014, authentic assessment is a form of assessment that requires learners to show attitudes, knowledge and skills gained from learning in carrying out tasks in real situations. Through authentic assessment, teachers can find out about the progress and learning achievements of learners who are able to express, prove and show appropriately that learning objectives have been fully mastered and achieved with motivation and attitudes towards learning.

One of the goals of learning Indonesian in school is that students are able to communicate well through four language skills, namely listening, speaking, reading, and writing. Morocco [4] states that the 21st century competencies that students must master in order for them to be able to play an active role are characterized by the possession of four skills or multiliteration abilities. The four skills are high comprehension reading skills, good writing skills to build and express meaning, skills to speak in an accountable manner, and skills to master various digital media and Information and Communication Technology (ICT). 
The direction of language learning is clearly on language skills, not on language knowledge. In fact, what the teacher evaluated was that there are still many who just dig into language knowledge alone, not in actual language activities. Thus, real language skills seem to be free from learning in school. Through authentic assessment, language skills will be precisely measured. The application of authentic assessment becomes an obligation for teachers. They must master it as a reference in assessing various language skills.

Based on this, the formulation of the problem in this study is 1) how is the application of authentic assessment in language skills learning?, 2) how are the forms of authentic assessment used in learning language skills?, and 3) how is the effectiveness of authentic assessments in improving learners' language skills?.

\section{LITERATURE REVIEW}

\subsection{Authentic Assessment}

Authentic assessment is an assessment in the form of a process of collecting various data that can provide an overview the development of learning of the learners. Authentic assessment is a process of collecting reporting and using information about learners' learning outcomes by applying the principles of assessment, continuous implementation, authentic, accurate, and consistent evidence as public accountability [17]. This understanding is in line with Majid [3] which interprets authentic assessment as a process of collecting various data that can provide an overview of the development of learners. The development of learners needs to be known by teachers to ensure that learners experience the correct learning process.

Based on the above description it can be understood that authentic assessment is interpreted as an attempt to evaluate the knowledge and skills of learners with real evidence and approach the real world or real life. The results of the assessment can be used as a reference to whether the learning objectives is achieved or not.

\subsection{Authentic Assessment of Productive Active Language Competence}

Receptive active language competence is related to the competence of listening and reading. Assessments of these two competencies usually use traditional assessments that use tests or answer questions. Assessment of both competencies can use authentic assessment, by changing the bill from just asking learners to respond to answers to productive active language performance bills both orally and in writing [5]. The determination should also not be separated from the basic competency and competency standards contained in the curriculum.

\subsection{Authentic Assessment of Productive Active Language Competence}

Productive active competency assessment is the ability to produce language to be delivered to others orally (speaking) or in writing [5]. Both of these competencies demand the assessment of language performances or the practice of using language. In contrast to receptive active competence that is more aimed at uncovering understanding of oral and written discourse, the speech and writing competency test is very appropriately assessed using authentic assessments.

Authentic tasks for speech competence include the performance of retelling something, telling stories based on certain excitations, giving verbal responses, discussing, talking, speaking, interviews, and others [5]. Authentic tasks for writing competence include correspondence, summarizing, summarizing, reviewing, books, writing news, writing articles, writing reports, advertisements, and so on [5]. As with receptive active language assessments, the determination of authentic tasks must also be adjusted to the applicable curriculum.

\section{METHOD}

The type of research used in this research is literature study research or literature studies (library research). According to Nazir [7] that literature study (library research) is a technique of collecting data using a study of books, pieces of literature, notes, and reports that have to do with solved problems, where to look for and analyze theories found that are relevant to authentic assessment in language learning.

This type of research is used by researchers to obtain data and information by reviewing written sources such as scientific journals and proceedings relevant to the title to be studied. The data source used is a secondary data source, namely accredited journals and proceedings regarding authentic assessments in language learning from 2009-2021 with a total of 25 journals and proceedings.

\section{RESULT AND DISCUSSION}

\subsection{Application of Authentic Assessment in Language Skills Learning}

Authentic assessment emphasizes the ability of learners to demonstrate their knowledge in a real and meaningful way. Assessment activities are not merely stating or intercepting knowledge that the learner already knows, but rather performing concretely from the knowledge and skills mastered. Authentic assessment is one form of assessment recommended since the Competency-Based Curriculum (KBK) and becomes an assessment that must be carried out in the 2013 Curriculum. Currently, teachers should have understood the concept of authentic assessment and have applied authentic assessment in learning in school. Authentic assessment in Indonesian learning can be seen from at least three indicators, namely absorption, understanding and assessment indicators.

The results of the data analysis showed that all teachers had carried out authentic assessments in learning. However, the application has not been fully 
done properly. One of the factors that cause this is that there are still teachers who do not understand the concept of authentic assessment. The lack of understanding of teachers about the concept of authentic assessment is shown through the results of nurgiyantoro and suyata research [6] said that in general teachers do not understand and carry out authentic assessments in language learning. Furthermore, it is only a small percentage of teachers who do not understand the concept of authentic assessment well. All teachers also claim to have applied authentic assessments even though they are not perfect.

Aside from the factor because the teacher has not understood the concept of authentic assessment, there are teachers who claim to have carried out authentic assessments but feel that the application has not been maximal because there are obstacles faced. One of the obstacles faced by teachers is still difficulty with the manufacture of assessment instruments. The implementation of the assessment has not fully used instruments that are in accordance with authentic assessment procedures because it still uses old judgments and tends to be subjective. Other obstacles that teachers encounter in the implementation of authentic assessments include: (1) time constraints; (2) difficulty implementing authentic assessment of certain competencies (3) complexity of implementing authentic assessments (4) learners.

It takes enough knowledge and understanding to properly apply authentic judgment. If knowledge and understanding have not been fulfilled, the application of assessment cannot be done properly. Educators or teachers must make certain actions or efforts to minimize the obstacles faced. According to Divanda et al [8] efforts to overcome the constraints of authentic assessment include: (1) teachers make plans that contain agreements between teachers and learners to conduct assessments at certain times and places; (2) the teacher considers assessments obtained from various sources; (3) teachers take various trainings that are authentic assessment concepts; (4) The school provides applications to determine the value of learners.

\subsection{Forms of Authentic Assessment used in Language Learning}

The importance of assessment in learning activities is undeniable. Assessment is something that can not be separated from learning activities. Good judgment should be done continuously. This is supported by Mulich [10] who states that assessments carried out intensively and regularly will foster good learning habits for learners. Based on the results of research [9] showed that in the implementation of authentic assessment teachers Indonesian on learning using question-and-answer techniques (tests) in knowledge assessment, portfolio techniques to assess the skills of learners, and performance techniques to assess the knowledge, attitudes, and skills of learners.
Furthermore, the results of the study [11] produced some form of authentic assessment applied in language learning. In attitude assessment, there are several forms of instruments used, including: (1) observation sheet instruments in the form of rating scales, (2) selfassessment sheets with checklists and rating scales, (3) assessment techniques between friends with checklist sheets and rating scales, and (4) journal assessment techniques using educators' daily cartatan. In the assessment of the knowledge, the teacher has used forms including: (1) written tests with the form of test descriptions accompanied by the technique of suspension and answer keys, (2) oral tests using a list of questions, and (3) assignment techniques with question / PR instruments, while in the assessment of skills teachers have also used various forms of assessment including (1) performance assessment in the form of checklist sheet, (2) project assessment technique with rating scale intrusion, (3) portfolio assessment with checklist assessment format, and (4) product assessment using checklist assessment format.

The results of the study [12] teachers conducted attitude assessments through observation techniques using journals, self-assessment, and between friends. Assessment of knowledge using written and oral test techniques through assignments with various forms of problems such as multiple choice and stuffing. In skill assessment, teachers use performance techniques i.e. products and practices, and use portfolio assessments.

Based on the results of the analysis data there are several forms of authentic assessment that are generally used in language learning as presented in the form of diagrams as follows.

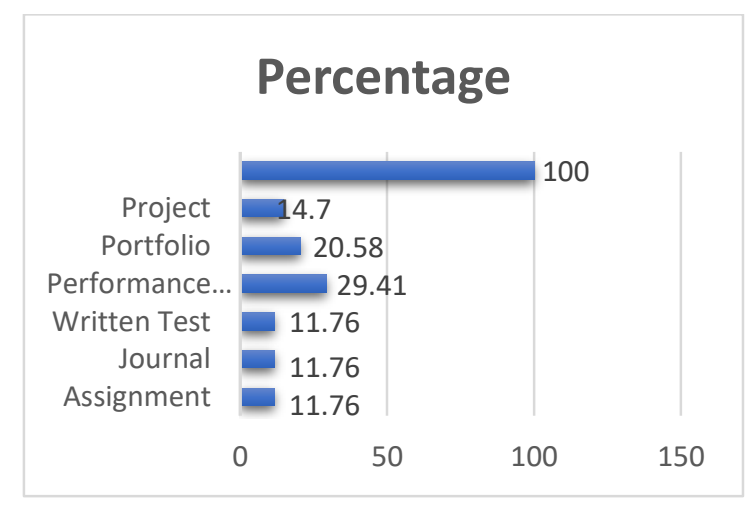

Figure 1. Forms of Authentic Assessment used in Language Learning

Figure 1 illustrates that the most dominant forms of authentic assessment used by teachers are performance assessment and portfolio assessment. Furthermore, the forms of assessment that are usually used are project assessments, written tests, journals, and assignments. The forms of authentic assessment used in language learning are described in detail as follows: 


\section{a. Attitude Competency Assessment (Affective)}

Educators conduct attitude competency assessments through observation, self-assessment, assessment between friends and journals.

(1) Observation is an assessment technique that is carried out continuously using the senses, either directly or indirectly using observation guidelines that contain several observed behavioral indicators.

(2) Self-assessment is an assessment technique that asks learners to assess themselves concerning status, process, and level of competency achievement in a particular subject.

(3) Assessment between friends or so-called peer assessment can be used for learners to evaluate the work of colleagues. This assessment includes a summative assessment that encourages learners to have a sense of responsibility for the learning process so that learners can be independent, practice the evaluation of skills that are useful for lifelong learning, and encourage deep learning. Assessment between friends can help increase the confidence of learners.

(4) Journal is a diary made by teachers or learners.

\section{b. Assessment of Knowledge Competence (Cognitive)}

(1) Written assessments that are following authentic assessments are assessments that ask learners not only to write the answers to questions briefly but to write descriptions or essays that require learners to be able to remember, understand, organize, apply, analyze, and synthesize the material that has been studied.

(2) Oral interviews can also be referred to as language performance assessments. As the name implies, in this activity there is a question and answer between the interviewee (student) and the interviewer (teacher, examiner) about what the information wants by the interviewer. However, in the context of the assessment of language learning outcomes the main purpose of the activity is to assess the competence of learners to discuss orally the information asked by the interviewer correctly. In the context of authentic assessment, the correct or incorrect language of learners is not solely judged by the accuracy of structure and vocabulary, but the accuracy or clarity of information conveyed as well as the function of language as a means of communicating.

(3) Assignments in the form of homework and or projects are undertaken individually or in groups following the characteristics of the task.

(4) Assignments in the form of homework and/or projects undertaken individually or in groups following the characteristics of the task.

c. Skill Competency Assessment (Psychomotor)

(1) Penilaian Performance assessment is often referred to as performance assessment. Performance assessment is intended to test learners' ability to demonstrate knowledge and skills, test what they know and can do, as found in real situations and specific contexts. Performance in the context of language learning results is related to active-productive performance through speech and writing.

(2) One form of authentic assessment is project-based assessment. Project assessment is a very complex class-based assessment because it covers psychomotor, cognitive, and affective aspects. Project assessment is a form of an assignment to produce certain works done in groups (e.g. three people) concerning the assessment of learning outcomes.

(3) Portfolio assessment is a collection of students' work collected deliberately, planned, and systemic which is then carefully analyzed to show the development of their progress at all times. Thus, as stated by Nurgiyantoro [5], the portfolio as one of the authentic assessments is appropriately used in the assessment process.

\subsection{Effectiveness of Authentic Assessment in Improving Language Skills}

Rukmana and Mundilarto [13] revealed that the implementation of this authentic assessment with good categories despite several obstacle factors in its implementation includes material, time, school conditions, and educators' abilities that are affected by the workload at school. Assessments on learning have been implemented authentically. Although the assessment has been done authentically, the assessment takes place less than optimally because it has obstacles in its implementation.

The constraints experienced by teachers Indonesian in the implementation of authentic assessments include (1) difficulty in managing time, (2) difficulty managing classroom situations that are not conducive, (3) facilities and infrastructure facilities that are less supportive, and (4) lack of teacher mastery of the assessment system implemented. These constraints are because authentic judgment is so complex that it demands a balance of judgment between knowledge, attitude, and skill. Inauthentic assessment there are also no instruments related to reading competence, so it is necessary to develop an authentic assessment model on reading learning.

In addition, Nurjananto and Kusumo [14] stated that effectively authentic assessment instruments can measure the competence of learners by each using different instruments according to needs. Based on data that refers to Susani's research [15] showed first, the results of extensive reading of learners gained an average of 80 so that it belongs to a very high category. Second, authentic implementation can provide benefits, such as 
(a) identifying the assessment directly from the expected competency indicators of the appearance of learners; (b) encouraging learners to demonstrate performance in real and meaningful situations; (c) providing learners the opportunity to build their learning outcomes by selecting and compiling answers based on knowledge and analysis of the situation so that relevant and meaningful answers; and (d) integrate teaching, learning, and assessment of activities.

Authentic assessments conducted by teachers can help teachers know how to learn learners, know in detail the ability of learners in learning, make it easier for teachers to provide evaluation materials that are following the needs of learners, provide teaching materials that are following the location of the student's learning place so that the tasks given by the teacher are related to the real-life of learners. This will be remembered by learners because learning is based on basic concepts that exist in everyday life. The authentic assessment model is particularly effective for evaluating oral Indonesian skills in high school [16]).

Based on the resulting data, it can be concluded that the authentic assessment model proved effective because authentic assessment as an assessment model is believed to be able to measure the success of learners' learning from the affective, cognitive, and psychomotor realms. Through authentic assessment, teachers gather information about student learning achievement, it is also useful for teachers to evaluate learning that suits the needs of students and improve the quality of teachers and schools in terms of learning.

\section{CONCLUSION}

From the results of the study, the author can conclude that first, the application of authentic assessments on language learning has not been maximal because teachers are still confused about the application of various assessment techniques in authentic assessment. Teachers still have difficulty in making assessment instruments. Other obstacles experienced by teachers in the implementation of authentic assessments include difficulty in managing time, difficulty managing classroom situations that are not conducive, facilities and infrastructure facilities that are less supportive, and lack of teacher mastery of the assessment system implemented. These constraints are because authentic judgment is so complex that it demands a balance of judgment between knowledge, attitude, and skill. Second, the most dominant forms of authentic assessment used by teachers are performance assessment and portfolio assessment. Furthermore, the forms of assessment that are usually used are project assessments, written tests, journals, and assignments. Third, the application of authentic assessment is effectively used in language learning because authentic assessment as an assessment model is believed to be able to measure the learning success of learners from the affective, cognitive, and psychomotor realms.

\section{ACKNOWLEDGMENTS}

The writers would like to express their sincere appreciation to colleagues and various parties who have helped write this article, either directly or indirectly so as to produce writing presented in front of readers.

\section{REFERENCES}

[1] Abdullah, S. R. (2014). Pembelajaran Saintifik untuk Implementasi Kurikulum 2013. Jakarta: Bumi Aksara.

[2] Mueller, J. (2013). Authentic Assessment Toolbox. North Central College. Retrieved from http://jfmueller.faculty.noctrl.edu/toolbox/index.ht m.

[3] Majid, A. (2014). Strategi Pembelajaran. Bandung: PT Remaja Rosdakarya.

[4] Morocco, C.C. (2008). Supported Literacy for Adolescents: Transforming Teaching and Content Learning for The Twenty-First Century. San Francisco: Jossey-Bass A Wiley Imprint.

[5] Nurgiyantoro, B. (2011). Penilaian Autentik dalam Pembelajaran Bahasa Berbasis Kompetensi. Yogyakarta: BPFE-Yogyakarta.

[6] Nurgiyantoro, B. \& Suyata, P. (2009). "Pengembangan Model Penilaian Authentic Assessment dalam Pembelajaran Bahasa". Jurnal Litera. 10 (2), 1-15.

[7] Nazir, M. (2013). Metode Penelitian. Bogor: Ghalia Indonesia.

[8] Divanda, A. D., Suwandi, S. \& Hastuti, S. (2018). "Implementasi Penilaian Autentik dalam Kurikulum 2013 pada Pembelajaran Bahasa Indonesia (Studi Kasus di SMA Negeri 1 Gemolong)". Basastra Jurnal Bahasa, Sastra, dan Pengajarannya, 6 (2), 12-19.

[9] Absari, I.G.A.K.L, Sudiana, N, \& Wendra, I.W. (2015). "Penilaian Autentik Guru Bahasa Indonesia dalam Pembelajaran Menulis Siswa Kelas VII di SMP Negeri 1 Singaraja". e-Journal Universitas Pendidikan Ganesha, 3 (1), 13-20.

[10] Muslich, M. (2010). Text Book Writing. Yogyakarta: Ar-Ruzz Media.

[11] Sriyono. (2017). "Implementasi Penilaian Otentik". Jurnal Pendidikan Surya Edukasi (JPSE), 3 (2).

[12] Adianto, S, Ikhsan, M \& Oye, S. (2020). "Penilaian Autentik pada Kurikulum 2013 dalam Pembelajaran Tematik di Sekolah Dasar". JINOTEP (Jurnal Inovasi dan Teknologi Pembelajaran) Kajian dan Riset dalam Teknologi Pembelajaran, 7 (2), 133-142.

[13] Rukmana, T., \& Mundilarto, M. (2016). "Keterlaksanaan Penilaian Autentik Mata Pelajaran Fisika SMA Negeri”. Jurnal Inovasi Pendidikan IPA, Vol. 2. Yogyakarta: Universitas Negeri Yogyakarta. 
[14] Nurjananto, N., \& Kusumo, E. (2015). "Pengembangan Instrumen Penilaian Autentik Untuk Mengukur Kompetensi Peserta Didik Materi Senyawa Hidrokarbon". Jurnal Inovasi Pendidikan Kimia, 9.

[15] Susani, R.G. 2018. "The Implementation of Authentic Assessment in Extensive Reading". International Journal of Education, 11 (1), 87-92.

[16] Wahyuni, S. (2010). "Pengembangan Model Asesmen Otentik dalam Pembelajaran Keterampilan Berbahasa Indonesia Lisan di Sekolah Menengah Atas (SMA)". Jurnal Litera, 9 (1), 69-79.

[17] Depdiknas. (2009). Kurikulum Tingkat Satuan Pendidikan. Jakarta: Pusat Kurikulum, Balitbang Depdiknas. 